УДК 616-007.43-089.844:615.468.67

DOI 10.11603/mcch.2410-681X.2019.v.i4.10840

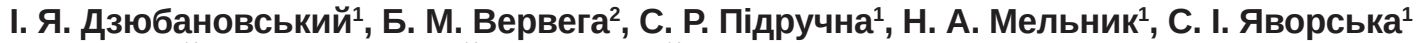
ТЕРНОПІЛЬСЬКИЙ НАЦІОНАЛЬНИЙ МЕДИЧНИЙ УНІВЕРСИТЕТ ІМЕНІ І. Я. ГОРБАЧЕВСЬКОГО МОЗ УКРАЇНИ

ЛЬВІВСЬКИЙ НАЦІОНАЛЬНИЙ МЕДИЧНИЙ УНІВЕРСИТЕТ ІМЕНІ ДАНИЛА ГАЛИЦЬКОГО

\title{
ДИНАМІКА ЗМІН ПОКАЗНИКІВ ЦИТОКІНОВОГО ПРОФІЛЮ У ТВАРИН З ГОСТРИМ ПОШИРЕНИМ ПЕРИТОНІТОМ НА ТЛІ ЦУКРОВОГО ДІАБЕТУ
}

Вступ. При гострому поширеному перитоніті будь-яке хірургічне втручання призводить до порушення імунного захисту з розвитком післяопераційних гнійно-септичних ускладнень, що збільшує в кілька разів вірогідність летального наслідку, особливо в осіб, які мають вторинний імунодефріцит на тлі цукрового діабету, порушення обміну речовин та ендотоксикозу.

мета дослідження - вивчити динаміку вмісту про- $і$ протизапальних цитокінів у сироватці крові щурів за умов експериментального гострого поширеного перитоніту на тлі цукрового діабету.

Методи дослідження. В експерименті було використано 56 білих щурів. Цукровий діабет моделювали шляхом внутрішньочеревного введення стрептозотоцину фрірми "Sigmal" з розрахунку 7 мг на 100 г маси щура, гострий поширений перитоніт - введення 0,5 мл 10 \% профрільтрованої калової суспензії в черевну порожнину піддослідних тварин. Показники цитокінового профрілю в сироватці крові визначали методом твердофразового імунофрерментного аналізу. Терміни спостереження - 1-ша, 3-тя, 7-ма доби від початку моделювання перитоніту.

Результати й обговорення. При порівнянні рівня інтерлейкінів між досліджуваними групами тварин відмічали статистично значуще більш вагоме підвищення рівня прозапальних цитокінів у щурів із цукровим діабетом протягом усіх термінів експерименту. Зокрема, концентрація інтерлейкіну $1 \beta$ достовірно зростала: на 1-шу добу спостереження - на 94 \%, на 3-тю - на 115 \%, на 7-му - на 121 \% порівняно 3 контрольною групою. Аналогічне значуще підвищення рівня фрактора некрозу пухлини а відзначали у тварин із цукровим діабетом. Найістотніше достовірне збільшення рівня цього показника в даній групі щурів зафріксували на 7-му добу експерименту - в 3,4 раза.

Висновок. При гострому перитоніті на тлі цукрового діабету суттєво зростає концентрація протизапальних цитокінів у сироватці крові тварин усіх груп, що підтверджує їх роль у патогенезі досліджуваної патології.

КЛЮЧОВІ СЛОВА: цитокіни; інтерлейкіни; гострий поширений перитоніт; цукровий діабет.

ВСТУП. Гострий поширений перитоніт (ГПП) дедалі частіше виникає із супутнім цукровим діабетом (ЦД), результатом чого є зміни механізмів його розвитку, погіршення наслідків лікування. Разом із тим, будь-яке хірургічне втручання призводить до порушення імунного захисту з розвитком післяопераційних гнійно-септичних ускладнень [1, 2], що збільшує в кілька разів вірогідність летального наслідку, особливо в осіб, які мають вторинний імунодефіцит на тлі хронічного захворювання, порушення обміну речовин та ендотоксикозу. Вже у ранній післяопераційний період виникають виражені розлади фрагоцитозу, клітинної та гуморальної ланок імунітету.

(ㄱ І. Я. Дзюбановський, Б. М. Вервега, С. Р. Підручна, Н. А. Мельник, С. І. Яворська, 2019.
На даний час перитоніт розглядають у динаміці запального процесу, який характеризується викидом про- та протизапальних цитокінів [3, 4]. До основних прозапальних цитокінів належать фрактор некрозу пухлини $\alpha$ (ФНП- $\alpha)$, інтерлейкіни

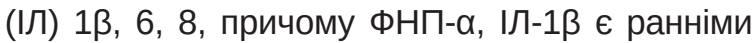
регуляторами імунної відповіді й індукують вивільнення вторинних цитокінів, таких, як ІЛ-6 та IЛ-8 [5, 6]. При прогресуванні перитоніту вироблення цитокінів відбувається відповідно до періодів (стадій) патологічного процесу: від активації синтезу з масивним каскадним викидом цитокінів до його пригнічення з розвитком імунопаралічу. Подальше прогресування гнійного запалення в черевній порожнині з приєднанням інших джерел ендогенної інтоксикації (в т. ч. 
пов'язаного з розвитком ентеральної недостатності) призводить до гіперактивації макрофрагів, нейтрофрілів, ендотеліальної системи, Т- і В-лімфоццитів та ін. [7, 8]. У зв'язку з цим, різко підвищується вміст цитокінів у крові й клітинах, які їх продукують, розвивається дисбаланс між медіаторами запалення і механізмами контролю їх вироблення в сторону гіперпродукування цитокінів, ейкозаноїдів, активних фрорм кисню (NO-, $\mathrm{O}_{2}^{-}, \mathrm{OH}^{-}, \mathrm{H}_{2} \mathrm{O}_{2}, \mathrm{ONO}_{2}^{-}$), стресорних гормонів та амінопептидів. Цитокіни, що циркулюють у крові, безперервно активують нові клітини з виникненням каскадної (некерованої) реакції з їх гіперпродукуванням (так званий "цитокіновий шквал”). При цьому спостерігають системні прояви (синдроми) токсичної дії цитокінів - синдром “протікання капілярів", синдром септикоподібного шоку та ін. Вони супроводжуються порушенням мікроциркуляції, вираженою вазодилатацією, перенаповненням венозного русла, підвищенням проникності судинної стінки і розвитком набряків, гіповолемією, гіпоксією тканин, зниженням артеріального тиску, гарячкою, метаболічним ацидозом тощо [9, 10]. За певних умов ці зміни переходять у сепсис, септичний шок та незворотну поліорганну недостатність.

Отже, в патогенезі ГПП на тлі ЦД цитокіни можуть відігравати значну роль, проте на сьогодні недостатньо з'ясовано конкретний механізм їх дії. Тому метою дослідження було вивчити динаміку вмісту про- і протизапальних цитокінів у сироватці крові щурів за умов експериментального гострого поширеного перитоніту на тлі цукрового діабету.

МЕТОДИ ДОСЛІДЖЕННЯ. В експерименті було використано 56 білих щурів, яких поділили на 3 групи: основна група - 24 тварини зі змодельованим ГПП на тлі ЦД; група порівняння 24 тварини зі змодельованим перитонітом; контрольна група - 8 інтактних тварин, яких утримували в стандартних умовах віварію. Усі порівнювані групи тварин були репрезентативними за масою, статтю і віком.

Експериментальний ЦД відтворювали шляхом внутрішньочеревного введення щурам стрептозотоцину натщесерце в дозі 60 мг/кг (фрірми "Sigmal"), який розчиняли в буферному натрієво-цитратному розчині (рH 4,5) [11]. Вміст глюкози визначали глюкозооксидантним методом о 9:00 год за умов вільного доступу піддослідних тварин до їжі та води протягом нічного періоду часу. Впродовж усього спостереження щурам вводили інсулін (0-2 ОД підшкірно 2-5 разів на тиждень).

Через 2 тижні з моменту застосування стрептозотоцину у венозній крові тварин, яку отриму- вали 3 хвостової вени, визначали вміст глюкози, і в подальших дослідженнях використовували тільки тих щурів, у яких вміст глюкози становив понад 300 мг/л. Тваринам контрольної групи замість стрептозотоцину підшкірно вводили стерильний 0,9 \% розчин натрію хлориду [7].

Вплив ЦД на перебіг ГПП вивчали на моделі, яку запропонували В. А. Лазаренко і співавт. [12]. Ця модель за етіологічними чинниками, клінічними проявами і фразністю перебігу близька до аналогічного процесу в людини. На 14-ту добу після введення стрептозотоцину тваринам основної групи вводили 10 \% профрільтровану калову суспензію в черевну порожнину піддослідних щурів у дозі 0,5 мл на 100 г маси тіла. Щурам групи порівняння лише підшкірно вводили калову суспензію. ІІї отримували шляхом змішування ізотонічного розчину і калу зі сліпої кишки 2-3 інтактних тварин, потім ії двічі фрільтрували через подвійний шар марлі. Одержану суспензію не пізніше ніж через 20 хв після приготування вводили інтактним щурам пункційним способом. щоб уникнути ушкодження внутрішніх органів при введенні калової суспензії в черевну порожнину, тварин тримали вертикально, каудальним кінцем угору. Методом пункції вентральної стінки в центрі середньої лінії живота, направляючи кінець голки по черзі у праве і ліве підребер'я, праву та ліву клубові ділянки, вводили однакову кількість калової суспензії.

Терміни спостереження - 1-ша, 3-тя і 7-ма доби. Експериментальне дослідження проводили з дотриманням загальних правил і положень Європейської конвенції про захист хребетних тварин, що використовуються для дослідних та інших наукових цілей (Страсбург, 1986).

Показники цитокінового профрілю в сироватці крові (ІЛ-1 $\beta$, ІЛ-10 та ФНП- $\alpha$ ) визначали методом твердофразового імуноферментного аналізу за допомогою набору реагентів "ELISA Kit for Rat Uscn, Life Science Inc." згідно з інструкціями фрірми-виробника.

РЕЗУЛЬТАТИ Й ОБГОВОРЕННЯ. На ДаНИЙ час немає сумнівів, що при ГПП на тлі ЦД реалізація активації специсрічних і неспецифрічних імунних реакцій пов'язана $з$ впливом на різні гомеостатичні системи організму цілого ряду універсальних медіаторів, серед яких важливе місце займають цитокіни. Їх часто називають клітинними гормонами, оскільки вони взаємодіють із специсрічними клітинними рецепторами, здійснюючи ауто-, пара-й ендокринну регуляцію. Цитокіни пріоритетно діють не тільки у вогнищі запалення і в зоні реагуючих лімфоїдних органів, а й на рівні всього організму, тому виникає не- 
обхідність дослідження інтерлейкінів у плазмі крові для вивчення системного характеру запалення при ГПП на тлі ЦД. За результатами дослідження (табл.), на 1-шу добу після моделювання ГПП (група порівняння) рівень ІЛ-1ß у сироватці крові статистично значуще зростав на 86 \%, тоді як на 3-тю - достовірно підвищувався на $104 \%$ відносно даних інтактних тварин, через тиждень досліду - на 107 \% порівняно з контрольною групою. У щурів із ГПП на тлі ЦД концентрація ІЛ-1 д достовірно збільшувалася: на 1-шу добу спостереження - на $94 \%$, на 3-тю - на $115 \%$, на 7-му - на 121 \% порівняно з контрольною групою.

При аналізі рівня протизапального ІЛ-10 в усі доби спостерігали статистично незначуще його зниження в сироватці крові піддослідних тварин із ГПП - на 11, 13 та 16 \% відповідно. Проведене дослідження показало, що рівень ІЛ-10 в сироватці крові щурів із ГПП на тлі ЦД на 1-шу добу достовірно зменшувався на $14 \%$, на 3-тю - на $17 \%$, на 7-му - на 15 \% порівняно 3 інтактними тваринами.

Рівень ФНП- $\alpha$ в сироватці крові тварин із змодельованим ГПП на 1-шу добу експерименту статистично значуще зростав у 3,2 раза, а на 3-тю і 7-му доби - в 3,3 та 3,4 раза відповідно. Аналогічне значуще підвищення досліджуваного показника ми спостерігали і в щурів основної групи. Найістотніше достовірне збільшення рівня ФНП- $у$ тварин із ГПП на тлі ЦД зафіксували на 7-му добу експерименту - в 3,4 раза.

Аналізуючи дані результати, можна зробити висновок, що моделювання ГПП на тлі ЦД призводить до порушення імунологічної та неспецисрічної реактивності організму.

Отже, ЦД характеризується прогресуючим погіршенням фрункції підшлункової залози, внас-

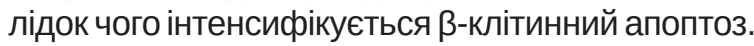

Відомо, що ІЛ-1ß може бути посередником апоптозу $\beta$-клітин. Інтерлейкін $1 \beta$ зв'язується 3 рецептором ІЛ-1 на поверхні цих клітин, що призводить до активації проапоптичних транскрипційних чинників NF-кB, фррагментації ДНК і втрати фоункціональної активності. Інтерлейкін $1 \beta$ активує ІкВ $\beta$-кінази і тим самим може викликати резистентність до інсуліну.

Таким чином, інтерлейкін $1 \beta$ може бути одним із чинників, які диференційно впливають на характер функціонування $\beta$-клітин підшлункової залози - від стимуляції до інактивації, що характерно для динаміки розвитку ЦД. Водночас метаболічні зсуви, які супроводжують це захворювання, зокрема гіперглікемія, є причиною довготривалого збереження підвищеної активності клітин, що продукують цитокіни, і тим самим сприяють прогресуванню хвороби. У результаті проведення досліджень встановлено, що за умов експериментального ГПП на тлі ЦД рівень ІЛ-1 у сироватці крові на 1-шу добу зростав на 94 \% порівняно $з$ інтактними тваринами.

Отримані дані свідчать про активацію макрофрагів, а також про можливість пригнічення

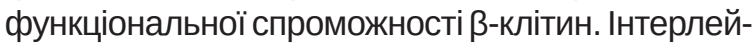
кін $1 \beta$ активує Т- і В-лімфоцити, посилює їх цитотоксичні властивості та ініціює синтез ФНП- $\alpha$.

ВИСНОВКИ. При гострому перитоніті на тлі цукрового діабету суттєво зростає концентрація протизапальних цитокінів у сироватці крові тварин усіх груп, що підтверджує їх роль у патогенезі досліджуваної патології. Зокрема, концентрація інтерлейкіну $1 \beta$ достовірно підвищилася: на 1-шу добу спостереження - на $94 \%$, на 3-тю - на $115 \%$, на 7-му - на $121 \%$ порівняно 3 контрольною групою. Аналогічне значуще зростання рівня фрактора некрозу пухлини $\alpha$ спостерігали у тварин із цукровим діабетом.

Таблиця - Рівень про- і протизапальних інтерлейкінів у сироватці крові

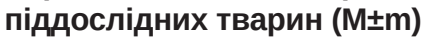

\begin{tabular}{|c|c|c|c|c|c|}
\hline \multirow{3}{*}{$\begin{array}{l}\text { Модель } \\
\text { досліду }\end{array}$} & \multirow{3}{*}{ Показник } & \multicolumn{4}{|c|}{ Група тварин } \\
\hline & & \multirow[b]{2}{*}{$\begin{array}{c}\text { інтактні } \\
(\mathrm{n}=8)\end{array}$} & \multicolumn{3}{|c|}{ піддослідні } \\
\hline & & & $\begin{array}{c}\text { 1-ша доба } \\
(n=8)\end{array}$ & $\begin{array}{c}\text { 3-тя доба } \\
(n=8)\end{array}$ & $\begin{array}{c}\text { 7-ма доба } \\
(n=8)\end{array}$ \\
\hline \multirow[t]{3}{*}{ ГПП } & ІЛ-1ß, нг/Л & $6,28 \pm 0,19$ & $\begin{array}{c}11,68 \pm 0,29 \\
p<0,05\end{array}$ & $\begin{array}{c}12,81 \pm 0,32 \\
p<0,05\end{array}$ & $\begin{array}{c}12,98 \pm 0,32 \\
p<0,05\end{array}$ \\
\hline & ІЛ-10, нг/л & $10,43 \pm 0,37$ & $\begin{array}{c}9,26 \pm 0,32 \\
p<0,05\end{array}$ & $\begin{array}{c}9,05 \pm 0,22 \\
p<0,05\end{array}$ & $\begin{array}{c}8,80 \pm 0,12 \\
p<0,05\end{array}$ \\
\hline & ФНП- $\alpha, \mathrm{Hг} / л$ & $1,56 \pm 0,11$ & $\begin{array}{c}4,96 \pm 0,19 \\
p<0,05\end{array}$ & $\begin{array}{c}5,20 \pm 0,19 \\
p<0,05\end{array}$ & $\begin{array}{c}5,23 \pm 0,19 \\
p<0,05\end{array}$ \\
\hline \multirow[t]{3}{*}{ ГПП на тлі ЦД } & ІЛ-1ß, нг/л & $6,28 \pm 0,19$ & $\begin{array}{c}12,21 \pm 0,22 \\
p<0,05\end{array}$ & $\begin{array}{c}13,48 \pm 0,45 \\
p<0,05\end{array}$ & $\begin{array}{c}13,90 \pm 0,32 \\
p<0,05\end{array}$ \\
\hline & ІЛ-10, нг/л & $10,43 \pm 0,37$ & $\begin{array}{c}8,98 \pm 0,17 \\
p<0,05\end{array}$ & $\begin{array}{c}8,70 \pm 0,32 \\
p<0,05\end{array}$ & $\begin{array}{c}8,86 \pm 0,22 \\
p<0,05\end{array}$ \\
\hline & ФНП- $\alpha$, нг/Л & $1,56 \pm 0,11$ & $\begin{array}{c}4,63 \pm 0,22 \\
p<0,05\end{array}$ & $\begin{array}{c}5,00 \pm 0,19 \\
p<0,05\end{array}$ & $\begin{array}{c}5,23 \pm 0,19 \\
p<0,05\end{array}$ \\
\hline
\end{tabular}


Найістотніше достовірне збільшення рівня цього показника в даній групі тварин засріксували на 7-му добу експерименту - в 3,4 раза.

За даних умов формується новий рівень регуляторних взаємозв'язків. При цьому важли- ву роль відіграють зміни в системі цитокінів макрофрагального походження. Це дозволяє вважати, що розвиток ускладнень при даній коморбідній патології пов'язаний із порушенням неспецифрічної ланки імунітету.

\section{СПИСОК ЛІТЕРАТУРИ}

1. Permanent peritoneal ports for the management of recurrent malignant ascites: a retrospective review of safety and efficacy / B. S. Chen, S. H. Wong, S. Hawkins, L. Huggins // Intern. Med. J. - 2018. - 48, No. 12. P. 1524-1528.

2. Synthetic mesh placement in the presence of abdominal infection: An experimental study of feasibility / A. B. Çiftci, R. H. Gündoğdu, B. O. Bozkırlı [et al.] // Ulus Travma Acil Cerrahi Derg. - 2018. - 24, No. 6. - P. 501506.

3. Noninvasive screening identifies patients at risk for spontaneous bacterial peritonitis caused by multidrugresistant organisms / P. G. Ferstl, M. Müller, N. Filmann [et al.] // Infect. Drug Resist. - 2018. - No. 11. - P. 20472061.

4. Immune tolerance therapy: A new method for treatment of traumatic brain injury / R. Y. Feng, Q. Chen, W. J. Yang [et al.] // Chin. Med. J. (Engl). - 2018. - 131, No. 16. - P. 1990-1998.

5. Outcomes of selective nonoperative management of civilian abdominal gunshot wounds: a systematic review and meta-analysis / A. N. Al Rawahi, F. A. Al Hinai, J. M. Boyd [et al.] // World J. Emerg. Surg. - 2018. - 27, No. 13. - P. 55.

6. Bacteriological profile of intra-abdominal infections in a tertiary care hospital / S. Sudhaharan, P. Kanne,
L. Vemu [et al.] // Iran J. Microbiol. - 2018. - 10, No. 4. P. 208-214.

7. Mohr R. How to reduce mortality of bacterascites that is the question / R. Mohr, P. Lutz // Liver Int. - 2018. 38, No. 12. - P. 2129-2131.

8. Methods to discriminate primary from secondary dengue during acute symptomatic infection / T. H. Nguyen, H. E. Clapham, K. L. Phung [et al.] // BMC Infect. Dis. 2018. - 18, No. 1. - P. 375.

9. Therapeutic electrical stimulation and immune status in healthy men / P. Novak, A. N. Kopitar, G. Vidmar [et al.] // Int. J. Rehabil. Res. - 2018. - 41, No. 4. P. 349-357.

10. Small Interfering RNA Targeting $\alpha$-Fodrin Suppressing the Immune Response of Sjögren's Syndrome Mice / X. L. Sun, C. Y. Pang, Y. Liu [et al.] // Chin. Med. J. (Engl). - 2018. - 131, No. 22. - P. 2752-2754.

11. Al-Malki A. L. Oat attenuation of hyperglycemiainduced retinal oxidative stress and NF-kkB activation in streptozotocin-induced diabetic rats / A. L. Al-Malki // Evidence-Based Complementary and Alternative Medicine. - 2013. - 2013. - Article ID 983923. - 8 p.

12. Experimental model of common fecal peritonitis / V. A. Lazarenko, V. A. Lypatov, Y. Y. Blynkov, D. V. Skorykov // Human and its Health. -2008. -4. - P. 128-132.

\section{REFERENCES}

1. Chen, B.S., Wong, S.H., Hawkins, S., \& Huggins, L. (2018). Permanent peritoneal ports for the management of recurrent malignant ascites: a retrospective review of safety and efficacy. Intern. Med J., 48 (12), 1524-1528.

2. Çiftci, A.B., Gündoğdu, R.H., Bozkırlı, B.O., Yazıcıoğlu, M.Ö., Öcal, B.G., \& Özdem, B. (2018). Synthetic mesh placement in the presence of abdominal infection: An experimental study of feasibility. Ulus Travma Acil Cerrahi Derg., 24 (6), 501-506.

3. Ferstl, P.G., Müller, M., Filmann, N., Hogardt, M., Kempf, V.A., Wichelhaus, T.A., Lange, C.M., et al. (2018). Noninvasive screening identifies patients at risk for spontaneous bacterial peritonitis caused by multidrug-resistant organisms. Infect. Drug Resist., 11, 2047-2061.

4. Feng, R.Y., Chen, Q., Yang, W.J., Tong, X.G., Sun, Z.M., \& Yan, H. (2018). Immune tolerance therapy: Anew method for treatment of traumatic brain injury. Chin. Med. J. (Engl.), 131 (16), 1990-1998.
5. Al Rawahi, A.N., Al Hinai, F.A., Boyd, J.M., Doig, C.J., Ball, C.G., Velmahos, G.C., et al. (2018). Outcomes of selective nonoperative management of civilian abdominal gunshot wounds: a systematic review and meta-analysis. World J. Emerg. Surg., 27 (13), 55

6. Sudhaharan, S., Kanne, P., Vemu, L., Chavali, P., Desmukha, S.R., \& Nagari, B. (2018). Bacteriological profile of intra-abdominal infections in a tertiary care hospital. Iran J. Microbiol., 10 (4), 208-214.

7. Mohr, R., \& Lutz, P. (2018). How to reduce mortality of bacterascites - that is the question. Liver Int., 38 (12), 2129-2131.

8. Nguyen, T.H., Clapham, H.E., Phung, K.L., Nguyen, T.K., Dinh, T.T., Nguyen, T.H., et al. (2018). Methods to discriminate primary from secondary dengue during acute symptomatic infection. BMC Infect. Dis., 18 (1), 375. 
9. Novak, P., Kopitar, A.N., Vidmar, G., Ihan, A., \& Štefančič, M. (2018). Therapeutic electrical stimulation and immune status in healthy men. Int. J. Rehabil. Res., 41 (4), 349-357.

10. Sun, X.L., Pang, C.Y., Liu, Y., Zhang, W., \& Wang, Y.F. (2018). Small interfering RNA targeting $\alpha$-fodrin suppressing the immune response of Sjögren's syndrome mice. Chin. Med. J. (Engl.), 131 (22), 27522754.
11. Al-Malki, A.L. (2013). Oat attenuation of hyperglycemia-induced retinal oxidative stress and NF-kkB activation in streptozotocin-induced diabetic rats. Evidence-Based Complementary and Alternative Medicine, 2013, 983923, 8. Retrieved from: https://www.hindawi. com/journals/ecam/2013/983923.

12. Lazarenko, V.A., Lypatov, V.A., Blynkov, Y.Y., \& Skorykov, D.V. (2008). Experimental model of common fecal peritonitis. Human and its Health., 4, 128-132.

И. Я. Дзюбановский믄. Б. Вервега ${ }^{2}$, С. Р. Пидручная ${ }^{1}$, Н. А. Мельник ${ }^{1}$, С. И. Яворская ${ }^{1}$ ТЕРНОПОЛЬСКИЙ НАЦИОНАЛЬНЫЙ МЕДИЦИНСКИЙ УНИВЕРСИТЕТ ИМЕНИ И. Я. ГОРБАЧЕВСКОГО МОЗ УКРАИНЫ ${ }^{1}$ ЛЬВОВСКИЙ НАЦИОНАЛЬНЫЙ МЕДИЦИНСКИЙ УНИВЕРСИТЕТ ИМЕНИ ДАНИЛА ГАЛИЦКОГО

\section{ДИНАМИКА ИЗМЕНЕНИЙ ПОКАЗАТЕЛЕЙ ЦИТОКИНОВОГО ПРОФИЛЯ У ЖИВОТНЫХ С ОСТРЫМ РАСПРОСТРАНЕННЫМ ПЕРИТОНИТОМ НА ФОНЕ САХАРНОГО ДИАБЕТА}

\section{Резюме}

Вступление. При остром распространенном перитоните любое хирургчческое вмешательство приводит к нарушению иммунной защиты с развитием послеоперационных гнойно-септических осложнений, что увеличивает в несколько раз вероятность летального исхода, особенно у лиц, имеющих вторичный иммунодефицит на фроне сахарного диабета, нарушения обмена веществ и эндотоксикоза.

Цель исследования - изучить динамику содержания про- и противовоспалительных цитокинов в сыворотке крови крыс в условиях экспериментального острого распространенного перитонита на фроне сахарного диабета.

Методы исследования. В эксперименте было использовано 56 белых крыс. Сахарный диабет моделировали путем внутрибрюшного введения стрептозотоцина фрирмы "Sigmal" из расчета 7 мг на 100 г массы крысы, острый распространенный перитонит - введения 0,5 мл 10 \% профильтрованной каловой суспензии в брюшную полость подопытных животных. Показатели цитокинового профиля в сыворотке крови определяли методом твердофразного иммуноферментного анализа. Сроки наблюдения - 1-е, 3-и, 7-е сутки от начала моделирования перитонита.

Результаты и обсуждение. При сравнении уровня интерлейкинов между исследуемыми группами животных отмечали статистически значимое более весомое повышение уровня провоспалительных цитокинов у крыс с сахарным диабетом в течение всех сроков эксперимента. В частности, концентрация интерлейкина 1ß достоверно возрастала: на 1-е сутки наблюдения - на 94 \%, на 3-и - на $115 \%$, на 7-е - на 121 \% по сравнению с контрольной группой. Аналогичное значимое повышение уровня фрактора некроза опухоли а отмечали у животных с сахарным диабетом. Наиболее существенное достоверное увеличение уровня этого показателя в данной группе крыс зафиксировали на 7-е сутки эксперимента в 3,4 раза.

Вывод. При остром перитоните на фроне сахарного диабета существенно возрастает концентрация противовоспалительных цитокинов в сыворотке крови животных всех групп, что подтверждает их роль в патогенезе исследуемой патологии.

КЛЮЧЕВЫЕ СЛОВА: цитокины; интерлейкины; острый распространенный перитонит; сахарный диабет. 


\section{DYNAMICS OF CHANGES OF CYTOKINE PROFILE INDICATORS IN ANIMALS WITH ACUTE GENERALIZED PERITONITIS ON THE BACKGROUND OF DIABETES MELLITUS}

\section{Summary}

Introduction. In acute peritonitis, any surgical intervention leads to impaired immune protection with the development of postoperative purulent-septic complications, which increases several times the likelihood of death, especially in persons with secondary immunodeficiency against diabetes mellitus.

The aim of the study - to learn the dynamics of pro- and anti-inflammatory cytokine content in rat serum under experimental acute peritonitis on the background of diabetes mellitus.

Research Methods. 56 white rats were used in the work. Diabetes mellitus was modeled by intraperitoneal administration of streptozotocin by Sigmal at a rate of $7 \mathrm{mg}$ per $100 \mathrm{~g}$ of animal weight, acute peritonitis - by introducing $0.5 \mathrm{ml}$ of $10 \%$ filtered stool suspension into the abdomen of the test animals. Determination of cytokine profile in serum was performed by enzyme-linked immunosorbent assay. Observation time: 1, 3, 7 days from the beginning of peritonitis modeling.

Results and Discussion. When comparing the levels of interleukins between the study groups of animals, a statistically substantial more significant increase in the level of proinflammatory cytokines was found in the group of diabetic animals during all experimental periods. In particular, the concentration of interleukin - $1 \beta$ increased significantly by 1 day of observation by $94 \%$, 3 day - by $115 \%$, and 7 day - by $121 \%$ compared to the intact group. Similarly, a significant increase in TNF- $\alpha$ levels was observed in animals with diabetes. The most significant significant increase in the level of this indicator in this group of animals was recorded on the 7th day of the experiment -3.4 times.

Conclusion. Animals with acute peritonitis on the background of diabetes significantly increase the concentration of anti-inflammatory cytokines in the serum of all study groups, which confirms their involvement in the pathogenesis of the pathology under study.

KEY WORDS: cytokines; interleukins; acute peritonitis; diabetes mellitus.

Отримано 23.10.19

Адреса для листування: С. Р. Підручна, Тернопільський національний медичний університет імені І. Я. Горбачевського мОз України, майдан Волі, 1, Тернопіль, 46001, Україна, e-mail: pidruchna@tdmu.edu.ua. 